\title{
Chinese Visions of World Order: Post-hegemonic or a New Hegemony?
}

\author{
William A. Callahan \\ University of Manchester
}

\begin{abstract}
Lately, there has been increasing interest among international relations (IR) scholars in Chinese thought, both as an alternative to Eurocentric IR, and because the PRC as an emerging power will soon have the institutional power to promote its view of the world. Rather than look for suitable Chinese parallels to "international," "security," or other mainstream concepts, this article will examine the concept of "Tianxia Allunder-Heaven" to understand Chinese visions of world order. Tianxia is interesting both because it was key to the governance and self-understanding of over two millennia of Chinese empire, and also because discussion of Tianxia is becoming popular again in the twenty-first century as a Chinese model of world order that is universally valid. After outlining a popular discussion of the "magnanimous" and all-inclusive Tianxia system, the article will examine some of the theoretical problems raised by this reading of Tianxia, in particular how its approach to "Otherness" encourages a conversion of difference, if not a conquest of it. It will conclude that Tianxia's most important impact will not be on the world stage, but in China's domestic politics, where it blurs the conceptual boundaries between empire and globalism, nationalism, and cosmopolitanism. Hence rather than guide us toward a post-hegemonic world order, Tianxia presents a new hegemony where imperial China's hierarchical governance is updated for the twenty-first century.
\end{abstract}

Lately, there has been increasing interest among international relations (IR) scholars in Chinese thought, both as an alternative to Eurocentric IR, and because the PRC as an emerging power will soon have the institutional power to promote its view of the world. While prominent Western experts have concluded that China is a status quo power that is unlikely to challenge the international system (Johnston and Ross 2006; Shambaugh 2006; Shirk 2007; Johnston 2008), an idealized version of China's imperial past is now inspiring Chinese scholars' and policymakers' plans for China's future-and the world's future. Rather than simply provide suitably Chinese parallels to "international," "security," or other mainstream IR concepts, many public intellectuals in Greater China have been promoting the ancient concept of "Tianxia" to understand Chinese visions of world order.

Tianxia is interesting both because it was key to the governance and self-understanding of over two millennia of Chinese empire, and also because

\footnotetext{
${ }^{1}$ I would like to thank the Centre for Chinese Studies at the University of Manchester and the British Academy/Chinese Academy Social Sciences visiting fellowship for funding fieldwork in China. I received helpful comments at the ISA 2007 symposium on Responsible Scholarship, and from Elena Barabantseva, David Blaney, Sumalee Bumroongsook, Paul A. Cohen, Dan Xingwu, Victoria Tin-bor Hui, Li Shaojun, Mustapha Kamal Pasha, Chih-yu Shih, J. Ann Tickner, Andrei P. Tsygankov, and Wang Yizhou.
} 
discussion of Tianxia is becoming popular again in the twenty-first century, in ways that go against China's official policy of peacefully rising within the international system. On the one hand, the premier historian of overseas Chinese, Wang Gungwu (2006b), chose "Tianxia and Empire" as the topic for his inaugural Tsai Lecture at Harvard. On the other, in April 2005 a prominent philosopher at the Chinese Academy of Social Sciences, Zhao Tingyang, published Tianxia tixi: Shijie zhidu zhexue daolun [The Tianxia System: A Philosophy for the World Institution] to describe a Chinese model of world order that is universally valid. The Tianxia System became a best-seller in China because it caught a wave of interest in Chinese-style solutions to world problems, and especially an interest in how the traditional concept of Tianxia combines the seemingly contradictory discourses of nationalism and cosmopolitanism.

While Chinese scholars have been employing traditional concepts-including Tianxia-to explain current domestic and foreign policies for over a decade (see Sheng 1995; Li 1999; Dan 2005:23-38), Zhao's plan for a Chinese-inspired world utopia provides an exemplary case of the workings of normative policymaking because it dramatically shifted these discussions from the margins to the mainstream. The popularity of Zhao's very singular understanding of Tianxia thus powerfully demonstrates a broader trend that will outlive the considerable impact of this particular book: "Chinese-style IR" has become a topic of conversation not just among public intellectuals and IR scholars, but also in the much broader arenas of popular culture and state policy as a sort of patriotic cosmopolitanism. In this way, the Tianxia system is the current answer to the perennial question that transfixes intellectuals and policy elites in Beijing: "what is China's proper role in the world?" Many Western scholars and policymakers likewise increasingly are asking "what does China want?" (Legro 2007; Carlson 2007:253ff) Hence, if the predictions about China overtaking the United States to be the dominant superpower in the next few decades are true, it is important to see how China would order the world.

To examine China's alternative worldview, we will first consider Zhao's discussion of how the all-inclusive Tianxia system would solve the world's problems through a world institution that embraces difference according to a "magnanimous" social grammar. Since Zhao is looking to the positive aspects of Chinese thought, the first section will summarize his argument. ${ }^{2}$ Then the second section will examine some of the philosophical and historical problems posed by this romantic understanding of Tianxia, in particular how its approach to an ethical world order encourages a "conversion" of difference, if not a conquest of it. The article will conclude that Tianxia's most important impact will not be on the world stage, but in China's domestic politics. The power of Tianxia comes less from the sophistication of its theoretical argument than from its strategic placement in China's discursive networks of power. The article will examine how Tianxia recently has been redeployed both by China's state intellectuals and public intellectuals among the Chinese diaspora in ways that blur the conceptual boundaries between empire and globalism, and hierarchy and cosmopolitanism. In the end, I will conclude that, rather than guide us towards a post-hegemonic world order, Tianxia presents a new hegemony that reproduces China's hierarchical empire for the twenty-first century. This article thus has two objectives: (1) to critically describe a non-Western worldview as a model of world order, and (2) to examine how ideas get put into play in Chinese foreign policymaking.

\footnotetext{
${ }^{2}$ This is more difficult than it may appear. The book contains three long chapters that utilize many of the same arguments and examples in sometimes contradictory ways. In a way, this book was not written as a single narrative, but is a collection of Zhao's musings on Tianxia. Moreover, the book is transnational in form as well as content-two of the three chapters were first presented and written in English (see Zhao 2006a), and only later translated into Chinese in a more detailed and polemical style. It is necessary to describe the Chinese-language edition because it informs broader debate over foreign policy in Greater China.
} 


\section{The Tianxia System}

The problem in international politics today, according to Zhao, is not "failed states" like Afghanistan but a "failed world," a disordered world of chaos. While many would see world disorder as a political or an economic problem (that would be solved by a better political or economic system), Zhao (2005:1) argues that world chaos is a conceptual problem: "to order the world we need to first create new world concepts which will lead to new world structures." Since he feels that Western concepts (especially those from the Westphalia system) have gotten us into this mess, Zhao boldly states that only the Chinese concept of Tianxia-literally translated as All-under-heaven-can do the conceptual work that is necessary for world order. Throughout his discussion, he plays with the definition of this ancient and often vague term, sometimes reading Tianxia as "the World," and other times understanding it as "Empire." Either way, Tianxia is presented as a legitimate world order that is very different from Western imperialism. Thus, Tianxia is a utopia that sets the analytical and institutional framework that is necessary for solving the world's problems. In other worlds, Tianxia is presented as a utopia that has practical applications.

\section{Tianxia: Three Interwoven Meanings}

In its most basic sense, Tianxia is a geographical term. Literally speaking, tian is the heavens, the sky, and what is on top, while xia is an indexical term meaning below, lower, inferior. Tianxia thus refers to everything below the sky, and thus is commonly used in classical texts to refer to "the earth" and "the (Chinese) world." But Zhao (2005:41, 123-24) argues that in addition to this material and geographical sense, Tianxia also contains two other important meanings that are not just descriptive, but normative: (1) Tianxia as "all the people," and (2) Tianxia as the "world institution." Each of these three meanings of Tianxiageographical, psychological, and institutional-is necessary and interdependent in Zhao's normative world. Here Zhao $(2005: 32,30)$ is directing his arguments at a much broader audience to tackle problems not just in political philosophy, but in political science. In this way he seeks to unify not only the world, but also the world of thought as well.

\section{Tianxia as "The World" Geographically}

Zhao argues that world chaos emerges from using the improper perspective to view the world, conceptualize its problems and thus formulate solutions. Arguing that the present Westphalian world order leads to conflict because it is based on competing national interests, Zhao tells us that we need to think about world order in terms of a truly global view. The world's problems are too big for any one nation, superpower, region or international organization. To counter the mainstream way of framing "the international," Zhao looks to an ancient passage from Lao zi's Daode jing (Chapter 54) that instructs us to "use the world [Tianxia] to examine the world [Tianxia].' Zhao uses this important passage to argue that Tianxia is more than a place: it is a method for looking at world problems and world order from a truly global perspective-thinking through the world in an "all-inclusive" (wuwai) way, rather than thinking about the world from an inferior national or individual perspective. ${ }^{3}$ Likewise, to have world order, we need to measure the world according to a world standard, rather than according to national interests. By thinking through the world with a "view from

\footnotetext{
${ }^{3}$ For a discussion of imperial China's transition in the late nineteenth century from a Tianxia-based world order to a state-centric view see (Levinson 1968:95-108).
} 
everywhere," Zhao (2005:108, 40) argues that we can have a "complete and perfect" understanding of problems and solutions that is "all-inclusive." World unity thus leads to world peace and world harmony.

\section{Tianxia as "All the People"}

The all-inclusive nature of Tianxia is more than geographical. Zhao uses it ethically to define the second notion of Tianxia as "all the people." Here he underlines how a proper Tianxia system does not have an "outside" either geographically or ethically because China's "magnanimous thought" does not reject "the Other" (2005:14, 30, 13). In China's all-inclusive Tianxia system distinctions between inside and outside, and even friends and enemies are more relative than absolute. While the West, according to Zhao (2005:51-54), starkly divides the world according to racial distinctions, Chinese thought unites it according to an ethical logic that is cultural. The goal of the Tianxia system is "transformation" ( $h u a)$ that changes the self and the Other, normatively ordering "chaos" by transforming the "many" into "the one" (2005:13). While Carl Schmitt (1996) defines politics as the practice of publicly distinguishing between enemies and friends, Zhao (2005:33) tells us that "Tianxia theory is a theory for 'transforming enemies into friends,' where 'transformation' seeks to attract people rather than conquer them."

The philosophical and political problem for Zhao is how to represent the interests of the people of Tianxia as a truly world interest. He argues-at length-that democracy is illegitimate for representing the world interest because (1) it is based on individual desires, which are manipulated in both elections and surveys, and (2) although democratic institutions may work in domestic politics they do not (and he argues cannot) work on a global scale. Since Zhao (2005:19) feels that democracy is an "erroneous" way of determining the people's will, he reasons that the people's general will needs to be determined by a "careful observation of social trends" by a Confucian-Leninist elite. Thus, the criteria to judge the people's heart is not "freedom" but "order"-which is one of the main themes of Chinese thought (that is, order/chaos). Tianxia, Zhao (2005:31) reminds us, refers to the greatest and highest order.

\section{Tianxia as the World Institution}

Since the Tianxia system is defined by order, Zhao argues that this alternative world order needs to be established and maintained through a world institution. Because Tianxia refers to the greatest order, its structure as the world institution has fundamental legitimacy (Zhao 2005:31). Zhao tells us that although the European Union and the United Nations seem to be super-state regional and world institutions, they are limited by a worldview that is based on nation-states. While the West organizes political life in terms of the three levels of "individual, community and nation-state," Zhao tells us that Chinese political thought looks to the levels of "Tianxia, state, and family." While the Western world prioritizes the individual and works in terms of the nation-state, the Tianxia system starts at the largest level, Tianxia, and orders political and social life in a top-down manner (Zhao 2005:17).

To sum up, Zhao tells us that the world has serious political problems that need to be solved first conceptually, and then institutionally. Zhao's arguments grow out of a more general feeling among Chinese intellectuals that China's ethical system of domestic and international order was destroyed by the violent tendencies of selfish (Western) nation-states that operated (and continue to operate) in the Westphalian world system. Zhao provides the Tianxia system as the solution to the world's problems, arguing that we need to think through 
the world to understand it, and thus effectively and legitimately govern it. Tianxia is a hierarchical system that values order over freedom, ethics over law, and elite governance over democracy and human rights. It is literally a "topdown" (that is, tian-xia) prescription for the world's ills. Employing a mixture of tradition and modernity, the book uses ancient texts to propose a very modern solution to the very modern problems of world order. Tianxia is presented as the proper all-inclusive master narrative of world order that will solve all the world's problems through a single master institution that has "no outside" and operates according to a "view from everywhere." Rather than being like contemporary philosophical debates that often question such master narratives, Zhao's reasoning is like popular strands of theoretical physics that seek the final "theory of everything."

\section{Philosophical and Social Criticism}

The Tianxia System is both an ambitious and an ambiguous work. While Zhao is certainly striking out in a new direction by exploring the theoretical possibilities of Tianxia, his argument is based on a cavalier use of a few key passages from Chinese thought, which upon closer consideration actually do not support his Tianxia worldview. Zhao's argument for thinking through the world is based largely on his reading of Chapter 54 of Lao zi's Daode jing: "use the world [Tianxia] to examine the world [Tianxia]." This passage is cited numerous times in each chapter; but Zhao usually takes it out of context. The larger passage is "use the self to examine the self, use the family to examine the family, use the neighborhood to examine the neighborhood, use the world to examine the world. How do I know that the workings of the world [Tianxia] are like this? From this" (translation based on Chen 1985:273-275). Thus while there is nothing in this passage that prioritizes Tianxia over other spaces of activity-and actually suggests that we start with the self, not with the world-Zhao (2005:62) reads it as a top-down hierarchy where "the superior levels have to exist, and where common interest comes from them more than from the units at the inferior levels." Zhao thus uses the Daode jing in very odd ways to support his argument for a hierarchical world order, and likewise plays fast and loose with other key classical Chinese texts to support his Tianxia system.

Criticisms of The Tianxia System by Chinese scholars tend to focus on these problems, and argue that Zhao does not have the proper historical and philosophical understanding of the Tianxia concept (see Zhang 2006). ${ }^{4}$ While Zhao has presented himself to international audiences as "The Chinese Perspective" (see Pieterse 2006:1255; Zhao 2006a), his Chinese critics argue that this Tianxia system is merely his own individual perspective, which is full of errors. Yet Tianxia itself is an empty term-it refers to everything except the heavens-that demands to be explained and interpreted in various different ways. Hence, to dwell on Zhao's textual problems would miss the point of the book. Zhao is very clear that he is not interested in joining the standard philosophical debate about the true meaning of ancient texts. Thus, Zhao does not mind that his book has generated much criticism-as I will argue in the conclusion, feeding off of critical commentary is actually the secret of his success. Zhao's (2005:16) project is actually to "transcend the historical limits" of Chinese tradition in order to explore the theoretical possibilities offered by Chinese thought for dealing with contemporary problems. As noted above, his Tianxia system is a utopia that has practical applications. Hence it is most important to focus on the political ethics of Zhao's Tianxia system.

\footnotetext{
${ }^{4}$ Also see email correspondence from Dan Xingwu, (June 14, 2007). I heard this criticism of Zhao's textual errors many times when I presented this research in Beijing in April 2007.
} 


\section{Social Theory}

In discussing the benefits of the Tianxia system, Zhao employs contemporary social theory's concept of self/Other relations to compare how analytical borders are drawn in China and the West (also see Zhao 2007). Here, he is following thinkers like Levinas (2000:75-88) and Bachelard (1994) in seeing social relations and space as ethical and normative practices. Connolly (1991:36-63) and Walker (1993) applied this mode of analysis to IR to question how foreign policy emerges when the national self performs its identity as a mode of exclusion of the Other as a foreign enemy. The critical aim of these theorists is to resist the urge to convert difference into Otherness, and thus let diverse modes of life exist.

Zhao's most important argument, then, is that Chinese thought and the Tianxia system provide a productive form of self/Other relations that does not exclude difference. But upon scrutiny, Zhao's statement that China and Tianxia are "allinclusive" runs into problems. His argument concentrates on how the West has absolutely excluded otherness, and has dealt with difference through conquest. Yet Todorov's (1984) analysis of early European encounters with America shows how violent conquest is only one mode of dealing with difference: conversion to the conqueror's worldview is another technique of imperial violence. In other words, although exclusion certainly is an important issue, it is also important to examine how self/Other relations work to include difference in hierarchical ways. Thus although Zhao's all-inclusive Tianxia system may not have an outside, its institutionally-backed "self" utilizes both absolute exclusion and hierarchical inclusion to marginalize three social groups: the West, the people, and other nations along China's frontier.

\section{Excluding "the West"}

Zhao's master narrative is based on a fundamental and absolute distinction between a moral China and an immoral West whose individualist thought system and Westphalian world system he feels need to be transcended. Although Zhao $(2005: 1,7)$ is very interested in how analytical frameworks set the terms of debate, he is going in a different direction from scholars such as Wang Hui (2003:146) who argue that to understand China it is essential to question such absolute distinctions: "So, just what are China's problems? Or, what methods or even language should be used to analyze them?...[since] the binaries of reform/conservatism, the West/China, capitalism/socialism, and market/[state] planning are still hegemonic concepts...problems can hardly be brought to light." Hence even though Zhao is very critical of how Western thought employs absolute binaries, he uses the same analytical framework of China/West to construct and exclude "the West" as the Other. In this sense, Zhao's Pax Sinica mission is quite similar to that of the Western imperial scholars whom he criticizes; he is likewise aiming to integrate culture and power (Said 1978), in what some now call China's "yellow man's burden" of using China's ethical mode of governance to pacify and civilize the world (see Nyiri 2006:106).

\section{Guiding the Masses}

As noted above, Zhao's main argument against democracy is that the world's masses are incapable of thinking through the world, and thus cannot be trusted to act in a truly world interest. He goes on-at length-to criticize common people as "blind followers, selfish, irresponsible, foolish, and vulgar." Zhao (2005:27) likewise worries about the legitimacy of a society that is dominated by "swindlers, petty people, whores, idiots, and scoundrels."' Zhao's solution is not 
to totally exclude the people, but to include them in a hierarchical way that is guided by the Confucian-Leninist elite.

\section{Conquering and Converting Other Nationalities}

Zhao does not give much historical evidence for the utility of the Tianxia model; he is more interested in the possibilities of pure thought than in the messy experience of history. Even so, at times Zhao does elaborate on what he means by an all-inclusive Tianxia that seeks to transform enemies into friends. But rather than stress how inside and outside are "intimately" interwoven (Bachelard 1994:217218), Zhao argues that Tianxia describes a place that is all part of the normatively good "inside," and thus lacks an outside (wuwai). While there are inside/ outside distinctions within the Tianxia system, Zhao feels that these relations are not of absolute Otherness, but of relative cultural difference. To explain these contingent social relations, Zhao appeals to imperial China's "tribute system" of concentric circles with the civilized imperial capital at the center flowing out to embrace the various "barbaric" peoples at the periphery. Rather than criticizing imperial China's "civilization/barbarism distinction," he argues that it is still useful, with "barbaric lands and tributary states serving as beneficial competitors" for Chinese civilization (2005:53, 59-61).

While Zhao stresses that these were not racial distinctions, this is a moot point. If we accept that "race" is a pseudo-scientific concept deployed to explain cultural differences, then the category of "racism" did not exist before modern science and social Darwinism. When Zhao (2005:54) says that the benefit of this "civilization/barbarism" interaction was an "objective discussion of the long term advantages and disadvantages of different cultures," it certainly sounds like a hierarchy of cultures analogous to modern racism and the PRC's current concern with the "population quality" of its national minorities. More to the point, these hierarchical cultural relations where the goal is to transform enemies into friends follows the logic of the other technique of imperial violence discussed above: conversion. While Zhao (2006a:36) suggests that we need to transform peoples by "improving their interests," Shapiro (2004:126) reminds us that community-building always entails community-destroying.

In current discussions of world order, it is popular to see traditional China as a benevolent and magnanimous empire that provided peace and stability for centuries before the arrival of Western imperialism in the nineteenth century. This narrative is now used in Chinese and Western IR texts to explain why China is not a threat to world order in the twenty-first century (Li 1999; Zhang 2001; Kang 2007). Yet this comparison of a war-mongering Westphalian Europe with a peace-loving imperial China employs a very narrow definition of "war" as an inter-state phenomena, and a very shallow understanding of China's historical experience (Kang 2003:65-66; Hui 2008). Actually, the Chinese state was often engaged in violent interactions with states and semi-states along its frontiers. In its first century, the Qing dynasty (1644-1911) expanded massively in the west, including a struggle over the northwest frontier with Czarist Russia and the Mongolian Zunghar state that lasted into the 1770s. Rather than being a case of Western imperial incursion into China (as it is presented in China's modern history textbooks), this episode is better understood as a violent struggle between three empires-the Manchu Qing, Czarist Russia, and the Mongolian Zunghar-which resulted in the annihilation of the Zunghar as a people (Perdue 2005:256-289). A key classical phrase that Zhao does not mention is instructive: "The Tianxia is united" [Tianxia yitong] describes "uniting the tianxia through conquest" (Wang GW 2006:3). This reflects how the Chinese empire at times had a para bellum policy where, as Johnston (1995:249-254) argues, war was a 
constant occurrence in a zero-sum game that employed both pure violence and absolute flexibility (also see Hui 2008).

Hence Zhao's argument that Tianxia is all-inclusive seems to miss the point that not everyone wants to be included. Some people want to stay different and outside. China's imperial and contemporary history in Tibet, Taiwan and Xinjiang is instructive for what happens to difference that prefers to stay outside and not be transformed into a "friend"-it is redefined as a terrorist separatist threat that warrants military action. China's legal claim to these territories is strong, but Zhao's point is to stress the ethical legitimacy of the Tianxia model, which is lacking. The main question then is not whether China has a pattern of self/Other relations that is similar to the West (or not) (Shih 2007), but how the Tianxia system addresses difference. Because Zhao figures his Tianxia system as "all-inclusive," any difference risks being converted into the sameness of the overarching (Chinese) self. Indeed as I am finishing the final version of this essay in April 2008, Zhao's "ethical possibilities" are being violently applied by the Chinese state in Tibet through the violent exclusion (which employs a grossly racialized language that demonizes whole populations) of people who want to maintain a different social system.

To sum up, this section has shown how Zhao's Tianxia utopia has serious theoretical problems both in terms of its cavalier reading of classical Chinese texts and its odd use of contemporary social theory's vocabulary of ethical relations in a way that promotes "conversion" rather than "conquest." Lastly, it is necessary to point out the irony of one of Zhao's main arguments. Each of the imperial systems that he criticizes-Roman, British and American-has had its own utopian ideal to inspire its governance regime: Pax Romana, the civilizing mission, white man's burden, free world, and so on. Hence, all of the "Western" empires discussed in The Tianxia System have likewise argued that they are best for the world as the manifestion of an altruistic philosophical project that is not only just, but also inevitable.

While Zhao understandably criticizes the West for universalizing its particular worldview at the considerable expense of other worldviews, is he doing anything different? Is not he trying to universalize the very particular Chinese concept of Tianxia in order to apply it to the world? And does not Zhao's Pax Sinica risk creating the very problems of an intolerant world order that he seeks to solve? Rather than a post-hegemonic world order, does not Tianxia script a new hegemony? This leads us to the next section's argument that the real meaning of the Tianxia system is not found in its alternative world order, but in what it can tell us about current debates in Beijing about identity, security and China's role in the world. In this way, Tianxia is a strong example of how domestic and international politics inform each other as part of a broader struggle over the meaning of "China."

\section{Conclusion: Rethinking China and Rethinking the World}

Although Zhao does not discuss it, the meaning of Tianxia is even more complex than the Empire/World dynamic. According to classical and modern dictionaries, Tianxia also means "China." This is one reason why Zhao's book is so popular: Tianxia is about China, and China's role in the world in the twenty-first century-which are very hot topics in the PRC and among overseas Chinese. According to many scholars, imperial China's Tianxia system of governance worked very well- until it was challenged by Western imperialism. Thus, in modern times, China was forced to build a modern nation-state to defend itself from these foreign challenges. The question that many Chinese scholars are now asking is whether it is time for China (which is now a strong nation-state) to engage in promoting, establishing or constructing Tianxia-not just for China's benefit, but for the benefit of the world. 
Whereas, in the early twentieth century, imperial China's hierarchical world order was seen as the problem, now many Chinese scholars see it as the solution to the world's ills. Since Chinese culture is taken to be superior, many feel that it is the duty of patriotic Chinese to spread Chinese values, language, and culture not just in Asia, but around the world (Nyiri 2006:106; Friedman 2008). Tianxia thus provides us with a heuristic device for understanding how Chinese elites view their role in the world, and the world itself (see Leheny 2006). This is where we come to the second objective of the article: to examine how new ideas emerge in China's foreign policymaking. Zhao's The Tianxia System is meaningful not just as a philosophical or an academic text. Its power and influence thus emerges not necessarily from its arguments-which one critic describes as "pale and weak" (Zhang 2006)—but from its position in a network of debates among public intellectuals, state intellectuals and political leaders about China's role in the world as a major power.

Among public intellectuals, Zhao's Tianxia theory is embedded in China's political culture that on the one hand has an enduring anxiety about unity and disunity (including order and chaos), and on the other has a strong tradition of utopian thought that seeks to address these perennial issues with the "complete and perfect world" (see Callahan 2004; Hua 2005; Zhao 2005:40). Thus, Zhao is not alone in looking to the past for China's future strengths: Zhang (2002) Yimou's film Hero (2002) concludes with the assassin being transformed into a hero when he decides not to kill the emperor, which is much like Zhao's goal of transforming enemies into friends. The lesson drawn from this historical parable is that the individual has to sacrifice himself and his kingdom for the greater good of the Tianxia empire, because as the hero reasons, "Only the King of Qin can stop the chaos by unifying Tianxia [through conquest]."

Hence Zhao's book is part of the broader discussion of how China will be a world power: the "Introduction" to The Tianxia System is called "Why we need to discuss China's worldview." Zhao (2005:1) feels that to be a true world power, China needs to excel not just in economic production, but in "knowledge production." To be a knowledge power, China needs to stop importing ideas from the West, and exploit its own indigenous "resources of traditional thought." Thus, the aim of his book is to "rethink China" so as to "restructure China." But because China's problems are the world's problems, we then need to rethink and restructure the world in terms of Tianxia.

Here Tianxia is embedded in an important debate about how China can fit into the world system as a "responsible great power" that has emerged through a network of liberal Chinese IR scholars over the past decade (see Wang YZ 1999; Xia 2001; Shih 2005). China is trying to prove to the world (especially the West) that it is no longer a revolutionary state that challenges international order, but is a "responsible" member of international society. The PRC has demonstrated this by pursuing a more multilateral foreign policy that includes expanding its membership in international organizations at both the regional and the global level. Zhao's (2005:3) "Introduction" also talks about China's "responsibility" to the world, but he adds a theoretical twist to argue that China will become a responsible great power not merely by amassing economic and military capabilities, but by "creating new world concepts and new world structures." Here the notion of a "responsible China" shifts dramatically from that of a conservative state that is responsible to the current world order to Zhao's Tianxia that is responsible for creating a totally new world order.

While "responsible China" appealed to a network of liberal IR scholars in China, a group of IR theorists in China is also very interested in Zhao's Tianxia system. This network is engaged in promoting a "Chinese style" of IR theory (see Song 2001). With China's recent economic growth, Chinese scholars have 
sought to carve out space for their own unique research in a transnational academic market. Thus many key IR scholars are hailing Zhao's Tianxia system as a way to create space for a "China school" of international studies in an intellectual environment that is dominated by Western IR (Qin 2006; Wang YW 2006). Indeed, the editors of China's top international studies journal, World Economics and Politics, invited Zhao to write the editorial page essay for their September 2006 issue (Zhao 2006b). Another group of elite IR scholars reprinted one of Tianxia tixi's chapters as the lead chapter in Chinese Scholars View the World: International Order (Zhao 2006c). But again, Zhao is doing more than contribute to this debate which sees the "China school" as an assertion of cultural sovereignty to protect China's unique way of understanding the world. Zhao is interested in transcending this chaotic (and nationalist) intellectual scene by unifying the world of thought under the banner of the Tianxia system.

Lastly, Zhao's writings are embedded in the discursive network of China's top political leaders; Tianxia's utopian themes resonate with Beijing's latest foreign policy narrative: "harmonious world." Just five months after The Tianxia System was published, President Hu Jintao outlined his four point plan for a "Harmonious World" at the United Nations in September 2005 (Hu 2005). Since then, the "harmonious world" formulation has dominated China's explanations for its responsible engagement with the world. Zhao (2006b:1) himself praises the Chinese government for "once again utilizing the resources of China's traditional thought" in its twin policies of building a "harmonious society" and a "harmonious world." Yu Keping (2007), who is a close advisor to Hu, very directly relates the concepts of "harmonious world" and Tianxia, seeing harmonious world as a "new take on the development of the ancient Chinese dream of Tianxia Datong (the great harmony of the world)." The relation of scholarship and government policy-especially the ties between philosophers and the foreign ministry-is certainly opaque in China. But recent studies have shown how broader social networks including think tank scholars and university professors are having an increasing impact on foreign policy debates in Beijing (Glaser and Medeiros 2007).

Tianxia is thus embedded in a broad discussion of Chinese visions of world order that includes a feature film like Hero, dozens of articles in prominent IR journals, and even the Chinese president's "harmonious world" foreign policy narrative. Zhao's ideas are not influential in the standard sense of everyone agreeing with his proposed Tianxia system: actually the film, academic articles and state policy all disagree with him on many important issues. Rather Zhao's ideas are indirectly influential according to a normative logic of power: he has been able to set the agenda, and thus productively generate a powerful discourse that sets the boundaries of how people think about China's past, present and future. Zhao does this by employing familiar vocabularies: for the general audience he talks of "sacrifice for Tianxia"; for liberal IR scholars he talks of China as a "responsible great power"; for IR theorists he discusses how China has its own "worldview" that is different from the West; and for Beijing's political elite his ideas resonate with China's "harmonious world" policy. Zhao actually has very different understandings of these key phrases from each of these groups, but he uses this familiar language to position himself at the center of these core discursive networks, and thus present his contrary views as the mainstream view. By rethinking China in this way, Zhao is also able to rethink the world, and thus set discursive boundaries to control popular understandings not just of the past and the present, but of the future as well (see Shapiro 2004:48). In this way, the Tianxia system is part of China's assertion of normative soft power, but in a way that complements China's hard power of economic and military strength. In other words, Tianxia is not a post-hegemonic ideal, so much as a proposal for a new hegemony. 
Perhaps, the best way to understand the role of The Tianxia System is to compare it to Samuel Huntington's (1993) high profile writings. The point is not whether Huntington's articles are intellectually sophisticated, or whether US policy is dictated or influenced by them. Rather the texts are powerful as polemics that define problems in specific ways that actually serve to limit the range of possible solutions. In this way, Huntington set the terms of the debate about post-Cold War international politics that in turn generated a certain range of responses. Even when these responses are critical of the clash of civilizations argument, they add to its influence by recirculating the idea that "civilization" is the key topic of debate for international politics.

Zhao (2005) was already famous among intellectuals in the humanities before he put together his thoughts on Tianxia. The Tianxia System worked to grow the market for a politically inflected discussion of Chinese utopia, and is provoking responses from both IR scholars and political leaders in China. By inserting his discussion of a Chinese utopia into powerful discursive networks, Zhao has asserted himself as the "mainstream" for discussions of China's future-and of the world's future. Zhao mainstreamed Tianxia not by making arguments that all would agree with; rather, Zhao was successful because he described this exotic idea in terms of already existing vocabularies and debates. People now have to respond to his arguments, even when they are discussing something else: nationalism, globalization, socialism, world peace, and so on (see Wang F-L 2006; Xiang 2006). ${ }^{5}$

Although The Tianxia System has serious theoretical problems, the book has quite successfully generated considerable social capital for Zhao as well as enhancing China's soft power as a source of a universally valid model of world politics. The power of Tianxia thus comes less from nuanced argument than from its strategic placement in China's discursive networks of power. Rather than guide us towards a utopian world order that will solve global problems, Tianxia is an example of the workings of normative power, in the sense that it re-centers Chinese understandings of world order as a patriotic activity in domestic politics. It helps us understand how ideas about foreign policy-including those that chafe with the official view-get put into play in Beijing as part of the domestic politics of China's national image.

Beijing says that China will peacefully rise as a responsible power within the present international system, and not challenge the structures and norms of world order. But the success of The Tianxia System shows that there is a thirst in China for "Chinese solutions" to world problems, and a hunger for nationalist solutions to global issues, especially when they promote a patriotic form of cosmopolitanism. This is the main significance of The Tianxia System in China's foreign policymaking. Indeed, it is not an isolated example but the sign of a broader trend where China's imperial mode of governance is increasingly revived for the twenty-first century.

In a broader sense, The Tianxia System's rise to prominence in China can serve as a cautionary tale for IR theorists. While it is popular to argue that the Westphalian system is flawed, it does not necessarily follow that alternative worldviews are any better. While it is admirable to engage in a "dialogue of civilizations," it is important that it does not become a clash of empires in the sense of promoting revived versions of British, Chinese, Indian, Islamic, Russian, (and so on) imperial regimes. Indeed, while the Westphalian system is rightly criticized for being state-centric, the Tianxia example shows how non-Western alternatives can be even more state-centric. Moreover, proposals for a "post-hegemonic" system often contain the seeds of a new (and often violent) system of inclusion and exclusion: Tianxia presents a popular example of a new hegemony where imperial China's hierarchical governance is up-dated for the twenty-first century.

\footnotetext{
${ }^{5}$ This, of course, includes the author.
} 


\section{References}

Bachelard, Gaston. (1994) The Poetics of Space. Boston: Beacon Press.

Callahan, William A. (2004) Remembering the Future: Utopia, Empire and Harmony in 21st Century International Theory. European Journal of International Relations 10(4):569-601.

Carlson, Allen. (2007) China's Conflicted Olympic Moment. Current History 106(September):252256.

Chen, Guying. (1985) Laozi: Zhu, Yi, Ji Pingjie [Laozi: Text, Notes and Comments]. Beijing: Zhonghua Shuju.

Connolly, William. (1991) Identity/Difference: Democratic Negotiations of Political Paradox. Ithaca: Cornell University Press.

Dan, Xingwu. (2005) Liang Daguoji Tixi de Chongtu yu jindai Zhongguo de Shengcheng [The Clash of Two International Systems and the Formation of Modern China]. PhD Dissertation, Chinese Academy of Social Sciences, International Politics Department.

Friedman, Edward. (2008) Where is Chinese Nationalism? The Political Geography of a Moving Project. Nations and Nationalism (in press).

Glaser, Bonnie S., and Evan S. Medeiros. (2007) The Changing Ecology of Foreign Policy-Making in China: The Ascension and Demise of the Theory of 'Peaceful Rise'. China Quarterly 190:291310.

Hu, Jintao. (2005) Build Towards a Harmonious World of Lasting Peace and Common Prosperity. New York: Speech at the Plenary Meeting of the United Nations' 60th Session, September 15.

Hua, Shiping. (2005) A Perfect World. Wilson Quarterly (Autumn):62-67.

Hui, Victoria Tin-bor. (2008) How China Was Ruled. The American Interest 3:4(Spring):53-65.

Huntington, Samuel P. (1993) The Clash of Civilizations? Foreign Affairs 72(3):22-49.

Johnston, Alastair Iain. (1995) Cultural Realism: Strategic Culture and Grand Strategy in Chinese History. Princeton, NJ: Princeton University Press.

Johnston, Alastair Iain. (2008) Social States: China in International Institutions, 1980-2000. Princeton, NJ: Princeton University Press.

Johnston, Alastair Iain, And Robert S. Ross, eds. (2006) New Directions in the Study of China's Foreign Policy. Stanford, CA: Stanford University Press.

Kang, David C. (2003) Getting Asia Wrong: The Need for New Analytical Frameworks. International Security 27(4):57-85.

Kang, David C. (2007) China Rising: Peace, Power and Order in East Asia. New York: Columbia University Press.

Legro, Jeffrey W. (2007) What China Will Want: The Future Intentions of a Rising Power. Perspectives on Politics 5(3):515-534.

Leheny, David. (2006) A Narrow Place to Cross Swords: 'Soft Power' and the Politics of Japanese Popular Culture in East Asia. In Beyond Japan: The Dynamics of East Asian Regionalism, edited by Peter J. Katzenstein and Takashi Shiraishi, pp. 211-233. Ithaca, NY: Cornell University Press.

Levinas, Emmanuel. (2000) Ethics as First Philosophy. In The Levinas Reader, edited by Sean Hand, pp. 75-88. Oxford: Blackwell Publishers.

Levinson, Joseph R. (1968) Confucian China and its Modern Fate. Berkeley, CA: University of California Press.

Li, Shaojun. (1999) Lun Zhongguo Wenmingde Heping Neihan: Cong Chuantong Dao Xianshi: Dui 'Zhongguo Weixie' Lun de Huida [The Peaceful Orientation of Chinese Civilization: from Tradition to Reality: a Response to 'China threat' Theory]. Guoji Jingji Pinglun 19:30-33.

Nyiri, Pal. (2006) The Yellow Man's Burden: Chinese Immigrants on a Civilizing Mission. The China Journal 56:83-106.

Perdue, Peter C. (2005) China Marches West: The Qing Conquest of Central Eurasia. Cambridge, MA: Harvard University Press.

Pieterse, Jan Nederveen. (2006) Emancipatory Cosmopolitanism: Towards an Agenda. Development and Change 37(6):1247-1257.

QIn, YaQIng. (2006) Guoji Guanxi Lilun Zhongguo Pai Shengcheng de Keneng He Biran [The Chinese School of International Relations Theory: Possibility and Necessity]. Shijie Jingji yu Zhengzhi 3:7-13.

SAID, Edward. (1978) Orientalism. New York: Vintage.

Schmitt, Carl. (1996) The Concept of the Political. Chicago, IL: University of Chicago Press.

Shambaugh, David, Ed. (2006) Power Shift: China and Asia's New Dynamics. Berkeley, CA: University of California Press. 
Shapiro, Michael J. (2004) Methods and Nations: Cultural Governance and the Indigenous Subject. New York: Routledge.

Sheng, Hong. (1995) Shenme Shi Wenming? [What is Civilization?]. Zhanlüe yu Guanli 5:88-98.

Shiн, Снiн-yu. (2005) Breeding a Reluctant Dragon: Can China Rise into Partnership and Away from Antagonism? Review of International Studies 31(4):755-774.

Shin, Chiн-yu. (2007) The West that is not Western: Self-Identification in the Oriental Modernity. Chicago: Paper Presented at the 48th Annual Meeting of International Studies Association, March.

Shirk, Susan. (2007) China: Fragile Superpower. New York: Oxford University Press.

Song, Xinning. (2001) Building International Relations Theory with Chinese Characteristics. Journal of Contemporary China 10(26):61-74.

Todorov, Tzvetan. (1984) The Conquest of America: The Question of the Other. New York: Harper Collins.

Walker, R. B. J. (1993) Inside/Outside: International Relations as Political Theory. Cambridge: Cambridge University Press.

WAng, Yızhou. (1999) Mianxiang 21 Shijiede Zhongguo Waijiao: Sanzhong Xuqiude Xunqiu Jiqi Pingheng [Towards a Chinese Diplomacy for the 21st Century: Pursuing and Balancing Three Needs]. Zhanlüe yu Guanli 6:18-27.

WAng, Hui. (2003) Contemporary Chinese Thought and the Question of Modernity. In China's New Order: Society, Politics, and Economy in Transition, edited by Theodore Huters, pp. 140-187. Cambridge, MA: Harvard University Press.

WAng, Fei-Ling. (2006). Heading Off Fears of a Resurgent China. International Herald Tribune. April 11, 2006.

Wang, Gungwu. (2006) Tianxia and Empire: External Chinese Perspectives, Inaugural Tsai Lecture. Cambridge, MA: Harvard University (May 4).

Wang, Yrwer. (2006) Tanxun Zhongguo de Xin Shenfen: Guanyu Minzu Zhuyi de Shenhua [Exploring China's New Identity: The Myth of Nationalism]. Shijie Jingii yu Zhengzhi 2:1-13.

XiA, Liping. (2001) China: A Responsible Great Power. Journal of Contemporary China 10(26):17-25.

Xiang, Lanxin. (2006) Jieyan Quqi, Shenyan Hexie [Stop Talking About [China's] Rise, Be Careful Discussing [World] Harmony]. Lianhe Zaobao (Singapore) March 26, 2006.

Yu, KePIng. (2007) We Must Work to Create a Harmonious World. China Daily (May 10).

Zhang, Yongjin. (2001) System, Empire and State in Chinese International Relations. Review of International Studies 27(December):43-63.

Zhang, Yimou, Director. (2002) Yingxiong [Hero].

Zhang, Shuguang. (2006) Tianxia Lilun He Shijie Zhidu: Jiu “Tianxia Tixi” Wenxue yu Zhao Tingyang Xiansheng [Tianxia Theory and World Order: Questions about Mr Zhao Tingyang's The Tianxia System]. Zhongguo Shuping.

Zhao, Tingyang. (2005) Tianxia Tixi: Shijie Zhidu Zhexue Daolun [The Tianxia system: A Philosophy for the World Institution]. Nanjing: Jiangsu Jiaoyu Chubanshe.

Zhao, Tingyang. (2006a) Rethinking Empire from a Chinese Concept “All-under-Heaven” (Tian-xia). Social Identities 12(1):29-41.

Zhao, Tingyang. (2006b) Guanyu Hexie Shijie de Sekao [Some thoughts about the Harmonious World]. Shijie Jingii yu Zhengzhi 9:1.

Zhao, Tingyang. (2006c) Tianxia Gainian yu Shijie Zhidu [The Tianxia Concept and the World System]. In Zhongguo Xuezhi Kan Shijie: Guoji Zhixu Chuan [Chinese Scholars View the World: International Order], edited by Qin Yaqing, pp. 3-35. Beijing: New World Press.

Zhao, Tingyang. (2007) Shen yu Shenwai: Rujia de Yige Moujue Wenti [The Self and the Other: An Unresolved Issue in Confucianism]. Renmin Daxue Xuebao 1:15-21. 